\title{
PENGARUH MODEL PEMBELAJARAN KOOPERATIF TIPE JIGSAW DAN TALKING STICK TERHADAP HASIL BELAJAR MATEMATIKA DI SDN MLAJAH 2 BANGKALAN
}

\author{
Zainal Arifin \\ STKIP PGRI Bangkalan \\ zainal@stkippgri-bkl.ac.id
}

\begin{abstract}
This study in general is to find out the effect of Jigsaw Cooperative Learning Model and Talking Stick on Learning Outcomes of Mlajah 2 Bangkalan public elementary school. In proving and analyzing this in data collection by giving questionnaires and pretest and post-test questions. Testing data analysis uses validity, reliability, normality and homogeneity tests and One Way Anova. The results of the study based on hypothesis testing using the first hypothesis SPSS obtained the value of Sig. of $0.006<0.05$, so it can be concluded that the type of jigsaw cooperative learning model has a significant effect on mathematics learning outcomes The second hypothesis is based on the results of hypothesis testing on the Sig values obtained. of 0,000<0.05, so it can be concluded that the learning model of talking sticks in class B also has a significant effect on student learning outcomes in mathematics and hypotheses using the third One Way Anova based on the results of hypothesis testing obtained by the Sig. of $0.029<0.05$, so it can be concluded that Talking Sticks are better compared to cooperative jigsaw types.
\end{abstract}

Keywords: Learning Model, Learning Outcomes

\begin{abstract}
Abstrak
Penelitian ini secara umum untuk mengetahui Pengaruh Model Pembelajaran Kooperatif Tipe Jigsaw dan Talking Stick Terhadap Hasil Belajar sekolah dasar negeri Mlajah 2 Bangkalan,. Dalam membuktikan dan mengalisis hal tersebut dalam pengumpulan data dengan memberi angket dan soal pretes dan post-tes. Pengujian analisis data menggunakan uji validitas, reliabilitas, uji normalitas dan homogenitas dan One Way Anova. Hasil penelitian berdasarkan pengujian hipotesis mengunakan SPSS hipotesis pertama diperoleh nilai Sig. sebesar 0,006 < 0,05, sehingga dapat disimpulkan model pembelajaran kooperatif tipe jigsaw berpengaruh signifikan terhadap hasil belajar matematika Hipotesis kedua berdasarkan hasil pengujian hipotesis pada diperoleh nilai Sig. sebesar $0,000<0,05$, sehingga dapat disimpulkan bahwa model pembelajaran talking stik pada kelas B juga memiliki pengaruh yang signifikan terhadap hasil belajar metematika siswa dan hipotesis menggunakan One Way Anova ketiga berdasarkan hasil pengujian hipotesis diperoleh nilai Sig. sebesar 0,029 < 0,05, sehingga dapat disimpulkan bahwa Talking Stick lebih baik dibadingkan dengan kooperatif tipe jigsaw.
\end{abstract}

Kata Kunci: Model Pembelajaran, Hasil Belajar 


\section{PENDAHULUAN}

Kemajuan suatu bangsa sangat ditentukan oleh kualitas sumber daya manusia, dengan kualitas sumber daya manusia tergantung pada kualitas pendidikannya. Pendidikan adalah suatu hal yang harus dipenuhi dalam upaya meningkatkan taraf hidup bangsa Indonesia agar tidak tertinggal dengan bangsa lain. Karena pada sistem pendidikan nasional harus mampu menjamin pemerataan pendidikan, peningkatan kualitas pendidikan, serta relevansi dan efisiensi manajemen pendidikan untuk menghadapi tantangan dan tuntutan perubahan kehidupan lokal, nasional, global sehingga diperlukan pembaharuan pendidikan secara terencana, terarah dan berkesinambungan. Untuk mewujudkan sistem pendidikan perlu adanya peran aktif dari semua pihak diantaranya adalah pemerintah, orang tua siswa, guru dan lain - lain.

Guru merupakan kunci utama dalam meningkatkan mutu dan kualitas pendidikan, mereka berada di titik utama dalam setiap usaha perubahan pendidikan yang diarahkan pada perubahahan kualitatif. Guru memiliki tanggung jawab untuk mengatur, mengarahkan, dan menciptakan suasana yang mendorong siswa untuk melaksanakan berbagai kegiatan dalam proses pembelajaran di kelas. Model pembelajaran yang dipakai oleh guru akan banyak berpengaruh terhadap cara belajar siswa yang mana setiap siswa mempunyai cara belajar yang berbedabeda.

Dalam usaha meningkatkan hasil belajar siswa, tidak terlepas dari peran seorang guru. Guru punya tanggung jawab besar dalam peningkatan prestasi belajar siswa. Mereka tidak boleh asalasalan dalam mengajar, asal menyampaikan materi, asal member tugas, asal memberikan penilaian, dan asal menerima gaji, tanpa memerhatikan karakteristik dan perkembangan akademik siswa-siswanya (Huda, 2011). Hal pertama yang dapat dilakukan demi meningkatkan mutu pendidikan yaitu membuat pelajaran matematika yang menyenangkan sehingga siswa tidak merasa bosan untuk mengikuti kegiatan belajar matematika yaitu dengan pembelajaran metode Kooperatif Tipe Jigsaw dan Talking Stick yang membiasakan siswa untuk bersifat nyaman dan menyenangkan. Melalui cooperative learning siswa akan lebih bebas dalam menemukan interaksi edukatif selain itu siswa juga dapat mengidentifikasi kemampuan kamunikasi matematika 
siswa.

\section{METODE}

Pada penelitian ini jenis penelitiannya adalah penelitian deskriptif kuantitatif. Penelitian yang digunakan bertujuan agar dapat memperoleh jawaban terhadap pertanyaan penelitian yang dipilih untuk mencapai tujuan penelitian, serta berperan sebagai alat dan pedoman untuk mencapai tujuan tersebut. Metode penelitan yang dilakukan dengan tujuan utama untuk memecahkan atau menjawab permasalahan yang sedang dihadapi pada situasi sekarang (Setiadi, 2013).

Peneliti mengumpulkan data melalui pretes dan postest. Penelitian ini menggunakan soal yang telah disusun sebelum pengumpulan data. Peneliti ini menggunakan soal pretes dan postest untuk mendata tentang pengaruh model pembelajatan kooperatif tipe jigsaw dan Talking Stick terhadap hasil belajar siswa.

Instrumen dalam penelitian ini menggunakan soal tes untuk mendata tentang pengaruh model pembelajatan kooperatif tipe jigsaw dan Talking Stick terhadap hasil belajar siswa.

Dalam penelitian ini pengambilan data dilakukan dengan menggunakan dua macam instrument yaitu instrumen yang berfungsi sebagai pendukung pembelajaran didalam kelas yaitu :

1. Rencana

Pelakasanaan

Pembelajaran

Pada penelitian ini diberikan perlaukan pada kelas VA dan kelas VB yang dilaksanakan sebanyak 3 kali pertemuan dengan instrument berupa : silabus, dan rencana pelaksanaan pembelajaran (RPP) dan soal.

2. Instrument Penilaian Hasil Belajar Menurut (Arikonto, 2012) Tes hasil belajar adalah serentetan pertanyaan atau soal latihan dan alat lain yang digunakan untuk keterampilan, pengetahuan, intelegensi, kemampuan dan bakat yang dimiliki oleh individu atau kelompok.

Dalam penelitian ini tes hasil belajar yang akan digunakan adalah soal yang dibuat oleh guru mengacu pada tes uraian sebanyak 10 butir soal. Alat tes tulis digunakan untuk mengetahui kemampuan hasil belajar siswa, dan didapatkan data aspek kognitif, sehingga guru dapat mengukur tingkat hasil belajar pada masing - masing siswa secara individu.

Teknik Teknik analisis dalam penelitian ini yang digunakan adalah : 


\section{Uji Validitas}

Suatu instrumen dikatakan valid jika instrumen ini mampu mengukur apa saja hendak di ukurnya. Mampu mengungkapkan bahwa mengungkap apa yang ingin diungkapkan. (Riduwan dan Sunarto, 2012:348). Mengungkapkan bahwa mengungkap aspek -aspek yang hendak diteliti, maka diperlukan alat ukur yang baik dan berkualitas. Alat ukur tersebut dapat berupa skala atau tes. Sebuah tes yang baik harus memiliki beberapa criteria antara lain valid, reliable, standar, ekonomis, dan praktis. Sebuah tes dikatakan valid jika ia memang mengukur apa yang seharusnya diukur, dalam bahasa yang hamper sama bahwa validitas adalah ukuran seberapa cermat suatu tes melakukan fungsi ukurnya.

\section{Uji Reliabilitas}

Dalam bahasa Indonesia diambil dari kata reability dalam bahasa Inggris berasal dari kata reliable yang artinya dapat dipercaya. Tes tersebut dikatakan dapat dipercaya jika memberikan hasil yang tepat apabila diteskan berkali-kali. Sebuah tes dikatakan reliable apabila hasil-hasil tes tersebut menunjukkan ketetapan.

\section{Uji Normalitas Data}

Uji normalitas bertujuan untuk menguji apakah dalam model regresi, variabel bebas dan terikat keduanya memiliki distribusi data normal atau tidak. Model regresi yang baik adalah memiliki distribusi data normal atau mendekati normal. Deteksinya adanya normalitas yaitu dengan melihat penyebaran data atau titik sumbu diagonal dari grafik. Menurut Gujarati (2010) deteksi normalitas dengan melihat penyebaran data (titik) pada sumbu diagonal dari grafik. Dasar pengambilan keputusan sebagai berikut:

a) Jika data menyebar disekitar garis diagonal dan mengikuti arah garis diagonal, maka model regresi memenuhi asumsi normalitas.

b) Jika data menyebar jauh dari garis diagonal atau tidak mengikuti arah garis diagonal, maka model regresi tidak memenuhi asumsi normalitas.

\section{Uji Homogenitas (Kesamaan Varian)}

Uji homogenitas varian bertujuan untuk mengetahui apakah data yang dianalisis homogenitas atau tidak uji homogenitas varian ini sangat diperlukan sebelum kita membandingkan dua kelompok atau lebih agar perbedaan yang ada bukan disebabkan oleh adanya perbedaan data kasar untuk menguji homogenitas varian 


\section{Uji Hipotesis}

Paired sample t-test digunakan apabila data berdistribusi normal. Paired sample ttest merupakan salah satu metode pengujian yang digunakan untuk mengkaji keefektifan perlakuan, ditandai adanya perbedaan ratarata sebelum dan sesudah diberikan perlakuan (Widiyanto, 2013). Uji signifikan parameter (uji t-test) pada dasarnya menunjukkan berapa jauh variable independen berpengaruh secara signifikan. Dalam uji t-test ini di gunakan level of signifikan $(\alpha)$ sebesar 5\% atau $\alpha=0,05$.

\section{HASIL DAN PEMBAHASAN}

Hasil belajar siswa berupa aspek kognitif dengan menggunakan instrument tes berupa pilihan ganda yang diberikan sesudah pembelajaran (posttes) sebanyak 10 soal. Data yang diperoleh meliputi data skor hasil belajar dari 50 siswa yang terdiri dari 25 siswa kelompok ${ }_{1}$ dengan model pembelajaran kooperatif tipe Jigsaw dan 25 siswa kelompok ${ }_{2}$ dengan model pembelajaran Talking Stick. Posttes bertujuan untuk mengetahui sejauh mana pengaruh model pembelajaran kooperatif terhadap hasil belajar Matematika siswa pada materi bentuk pejumlahan pecahan

\section{Hasil Uji Validitas}

Validitaas dalam penelitian ini digunakan sebagai alat ukur yang menunjukkan tingkat kevalitan atau kesahitan suatu instrument. Untuk menguji validitas instrument ini digunakan aplikasi IMB SPSS v21.0. Dengan kriteria pengujian apabila $\mathbf{r}_{\text {hitung }}$ $>\mathrm{r}_{\text {tabel }}$ dengan $\alpha=0,05$ maka alat ukur tersbut dinyatakan valid dan sebaliknya apabila $\mathrm{r}_{\text {hitung }}<\mathrm{r}_{\text {tabel }}$ maka alat ukur tersebut dinyatakan tidak valid.

Berdsarkan kriteria, hasil penelitian uji coba tes tulis mengenai bentuk pejumlahan pecahan terdapat 10 butir soal valid. Hasil perhitungan uji reliabilitas skala hasil belajar (posttest) sebesar 0,787, hal ini membuktikan bahwa hasil skala dari hasil belajar memiliki tingkat reliabilitas, hal ini dibuktikan dengan kriteria pengujian yang mana apabila $\mathrm{r}_{\text {Alpha }}>\mathrm{r}_{\text {tabel }}$ maka dinyatakan reliable $\left(r_{\text {Alpha }} 0,787>r_{\text {tabel }}\right.$ $0.3233)$.

\section{Hasil Uji Normalitas}

Hasil dari uji normalitas di peroleh bahwa tes tulis atau posttest kedua model pembelajaran tersebut berdistribusi normal karena memenuhi kriteria, kelas dengan perlakuan model pembelajaran kooperatif tipe jigsaw 0,346>0,05 dan pada kelas dengan perlakuan model pembelajaran Talking Stick 0,107>0,05. 


\section{Hasil Uji Homogenitas}

Berdasarkan kriteria uji homogenitas, bila nilai sig. > 0,05 maka data diasumsikan memiliki varians yang sama, tetapi apabila nilai sig. < 0,05 maka data diasumsikan memiliki varians yang sama. Hasil pengujian homogenitas diatas menunjukan bahwa data memiliki varians yang sama dengan nilai sig. 0,009 yang artinya lebih kecil dari 0,05 atau $(0,009>0,05)$.

\section{Hasil Uji Paired Sample T-Test}

Berdasarkan hasil uji Paired Sample TTest pada tabel 4.7 menunjukkan bahwa model pembelajaran kooperatif tipe jigsaw pada kelas A didapat sig. sebesar 0,006 $<$ sig.taraf kesalahan sebesar 0,05 maka $\mathrm{H}_{0}$ ditolak dan $\mathrm{H}_{\mathrm{a}}$ diterima. Artinya model pembelajaran kooperatif tipe jigsaw berpengaruh signifikan terhadap hasil belajar matematika siswa kelas V SDN Mlajah Bangkalan. Sedangkan pada Kelas B dengan model pembelajaran talking stick diperoleh hasil data diman nilai sig. sebesar 0,000 $<0,05$ maka dapat diartikan bahwa model pembelajaran talking stik pada kelas B juga memiliki pengaruh yang signifikan terhadap hasil belajar siswa kelas V SDN Mlajah Bangkalan.

\section{Hasil Uji One Way ANOVA}

Tabel 1. Hasil uji anova

\begin{tabular}{|l|r|r|r|r|r|}
\hline & $\begin{array}{c}\text { Sum of } \\
\text { Squares }\end{array}$ & df & Mean Square & F & \multicolumn{1}{c|}{ Sig. } \\
\hline Between Groups & 46,080 & 1 & 46,080 & 5,097 &, 029 \\
\hline Within Groups & 433,920 & 48 & 9,040 & & \\
\hline Total & 480,000 & 49 & & & \\
\hline
\end{tabular}

Berdasarkan tabel diatas bahwa nilai sig. memiliki data yang signifikan. sebesar $0,029<0,05$ yang mengindikasikan bahwa terdapat pengaruh yang signifikan pada hasil belajar Matematika dengan diberikan 2 perlakuan antara model pembelajaran kooperatif tipe jigsaw dan talking stick. Jadi $\mathrm{H}_{0}$ ditolak dan $\mathrm{H}_{\mathrm{a}}$ diterima dimna hasil ANOVA tersebut bersifat menyeluruh yaitu secara bersamaan
Hasil pengujian pada tabel diaatas menunjukan bahwa $F_{\text {hitung }}$ sebesar 5,097 $>\mathrm{F}_{\text {tabel }}$ sebesar 4,04 yang artinya terdapat pengaruh model pembelajaran kooperatif tipe jigsaw dan talking stick terhadap hasil belajar Matematika kelas V SDN Mlajah Bangkalan. 


\section{KESIMPULAN}

Berdasarkan hipotesis yang diajukan serta hasil analisis data yang diperoleh dalam penelitian ini, maka peneliti memberikan beberapa kesimpulan yaitu Pada hasil uji Paired Sample T-Test model pembelajaran kooperatif tipe jigsaw pada kelas A didapat sig. sebesar $0,006<$ sig.taraf kesalahan sebesar 0,05 maka $\mathrm{H}_{0}$ ditolak dan $\mathrm{H}_{\mathrm{a}}$ diterima. Artinya model pembelajaran kooperatif tipe jigsaw berpengaruh signifikan terhadap hasil belajar matematika siswa kelas V SDN Mlajah Bangkalan. Pada hasil uji Paired Sample T-Test Kelas B dengan model pembelajaran talking stick diperoleh hasil data dimana nilai sig. sebesar $0,000<0,05$ maka dapat diartikan bahwa model pembelajaran talking stik pada kelas B juga memiliki pengaruh yang signifikan terhadap hasil belajar siswa kelas VII. Berdasarkan hasil uji One Way ANOVA diperoleh nilai sig. sebesar 0,029 $<0,05$ taraf signifikan yang mengindikasikan bahwa terdapat pengaruh yang signifikan dimana talking stick memiliki rata - rata nilai lebih tinggi dibandingkan kooperatif tipe jigsaw terhadap hasil belajar Matematika dilihat dari hasil rata-rata dari setiap model pembelajaran dimana model jigsaw memiliki rata-rata 75,24 sedangkan model talking stick memiliki rata-rata 77,16.

\section{DAFTAR PUSTAKA}

Huda, M. (2011). Cooperative Learning. Yogyakarta: Pustaka Belajar.

Setiadi. (2013). Konsep dan Praktek Penulisan Riset Keperawatan (Ed 2). Yogyakarta: Graha Ilmu

Sudjana, N. (2010). Cara belajar siswa aktif dalam proses belajar mengajar. Lampung: Sinar Baru Algensindo.

Sugiyono, (2011) Metode Penelitian Kuantitatif, Kualitatif dan R\&D, Bandung: Alfabeta,

Sunarto, R. d. (2007). Pengantar Statistika Untuk Penelitian Pendidika, Sosial, Ekonomi, Kominikasi dan Bisnis. Bandung: Alfabeta.

Umar, H. (2003). Metode Riset Bisnis. Jakarta: PT Gramedia Pustaka Utama. 